\title{
Geothermal Management Policy in the Order of Energy Independence in Aceh Besar District
}

\author{
Yanis Rinaldi ${ }^{1, *}$ Irvianty Irvianty $^{2}$ \\ ${ }^{1}$ Law Faculty of Syiah Kuala University, Banda Aceh, Indonesia \\ ${ }^{2}$ Mathematics and Natural Sciences Faculty of Syiah Kuala University, Banda Aceh, Indonesia \\ *Corresponding author. Email: yanisrinaldi@unsyiah.ac.id
}

\begin{abstract}
Aceh Besar District has many potentials for new and renewable energy, one of which is geothermal energy. In order for geothermal energy management to provide economic benefits, be accepted by the community, and be safe from environmental aspects, its management must be formulated in a regional policy document. The research objective is to explain geothermal energy management policies in Aceh Besar District. This research is a type of normative legal research with a statutory approach. The main research data is secondary data. The results showed that the Aceh Besar District Government had formulated geothermal utilization planning policies in the Medium-Term Development Plan, Strategic Environmental Assessment, and Regional Spatial Planning. The formulation of geothermal management policies in Aceh Besar District refers to the Law on Geothermal Energy, Electricity, and Aceh Qanun Number 4 of 2019 concerning the General Plan for Aceh Energy. The geothermal policy that has been realized is exploration activities for the Geothermal Power Plant in Seulawah Agam.
\end{abstract}

Keywords: Policy, Management, Geothermal.

\section{INTRODUCTION}

In Law No. 30 of 2009 concerning Electricity is mentioned primary energy sources that are domestic and/or originating from abroad must be optimally utilized in accordance with the national energy policy to ensure the availability of sustainable electricity.

The availability of electrical energy in Aceh is currently around 250 megawatts. Aceh still depends on the electricity supply from North Sumatra around 180 250 megawatts[1]. Meanwhile, the peak load is 448.3 MW[2]. The data shows that Aceh Province is still in a crisis of electrical energy so that there are frequent blackouts.

In an effort to spur energy development to meet electricity needs, the Government of Aceh has carried out development in the electricity sector, with an emphasis on developing new and renewable energy resource potentials, such as water, geothermal, solar, and biomass energy resources.[3]

Aceh Province is one of 26 provinces in Indonesia that has the potential for geothermal energy. Aceh's speculative geothermal energy potential is $625 \mathrm{MWe}$, hypothetical $533 \mathrm{MWe}$, and reserves of $215 \mathrm{MWe}$. Aceh's geothermal energy potential is spread over 17 locations in 8 districts/cities. This potential is found in Aceh Besar District, which is located in Ie Seum Krueng Raya with a hypothetical potential of $63 \mathrm{MWe}$ and Seulawah Agam with a potential of $165 \mathrm{MWe[4].}$

Geothermal energy is renewable energy as a national asset controlled by the state and used for the greatest prosperity of the people. Control of Geothermal by the state is carried out by the Government, provincial governments, and district/city governments in accordance with their respective authorities and based on the principles of utilization.[5] Geothermal is a source of heat energy contained in hot water, water vapor, and rocks along with associated minerals and other gases that are genetically inseparable in a Geothermal system.[6] Geothermal energy is environmentally friendly because in its utilization it only produces a few elements that have an impact on the environment or are still within the applicable regulatory limits. Thus, the utilization of Geothermal Energy has helped the Government's program to utilize clean energy 
while simultaneously reducing greenhouse gas emissions.

In several cases of the utilization of geothermal energy in Indonesia, human rights violations have occurred. One of the human rights that has been violated is the right to a good and healthy environment. The right to a good and healthy environment has been recognized and guaranteed by the 1945 Constitution as a human right. The utilization of geothermal energy in Mataloko, Ngada City, NTT has caused ecological impacts in the form of reduced water sources, damage to agricultural land, death of agricultural / plantation crops, crop failure, death and loss of long-lived wood species such as albesia, mahogany, avocado trees, and the palm tree. Other impacts include environmental damage, such as fracking and minor earthquakes, water pollution and erosion, [7] damage to protected forests, erosion, deforestation, and the emergence of waste due to drilling.

The utilization of geothermal energy cannot be separated from government policy, because the control is carried out by the state. James E. Anderson revealed that policy is "a purposive course of action followed by an actor or set of actors in dealing with a problem or matter of concern"[8]. This paper will examine the policies of the Aceh Besar District Government in managing geothermal energy in Seulawah Agam with a capacity of $55 \mathrm{MWe}$.

Based on the background of the problem, the formulation of the problem in this study is how the geothermal management policy in Aceh Besar District and the geothermal management of Seulawah Agam in Seulimeum and Mesjid Raya sub-districts.

\section{RESEARCH METHOD}

This research is a type of normative legal research[9] or doctrinal legal research[10], using a statute approach. The main research data is secondary data. Data collection was done through a documentation study. The collected data is processed and analyzed using content analysis.

\section{FINDINGS AND DISCUSSION}

\subsection{Aceh Besar District Government Policies in Geothermal Energy Management}

In the 2017-2022 Aceh Besar District Medium Term Development Plan which is stipulated by the Regional Regulation (Qanun) of Aceh Besar District No. 2 of 2019, geothermal management policies have been included in Chapter IV, sub-chapter Development Problems. This policy was born due to two considerations. First, population growth; second, the plan to develop the Aceh Industrial Estate in Ladong, Mesjid Raya District. In the Aceh Industrial Zone, several large industrial companies will operate. To meet the growing need for electrical energy, the Aceh Besar District Government needs to increase the availability of electrical energy by utilizing the potential of geothermal energy.

Geothermal energy management policies have also been included in the 2012-2032 Regional Spatial Plan for Aceh Besar District which was stipulated by Qanun Aceh Besar District No. 4 of 2013. In the Energy Network System paragraph, Article 19 paragraph (2) letter b, it is stated that the energy network system consists of electric power plants and energy infrastructure networks. The power plant consists of a hydroelectric power plant, a micro hydropower plant, and a geothermal power plant (PLTP). The PLTP will utilize the geothermal energy of Mount Seulawah Agam in Lamteuba Village, Seulimeum District with a capacity of $250 \mathrm{MW}$. Furthermore, Article 36 paragraph (1) letter e states that areas designated for mining include, among other things, geothermal designated areas. In paragraph (6) it is stated that the geothermal designated areas in the form of geothermal energy potential are located in Seulimum District, Lembah Seulawah District, and Mesjid Raya District.

Article 3 of Law no. 21/2014 concerning Geothermal states that the implementation of geothermal activities aims to: (1) control Geothermal exploitation activities to support energy security and independence in order to support sustainable development and provide maximum benefits for the welfare and prosperity of the people; (2) increasing the use of renewable energy in the form of geothermal energy to meet national energy needs; and (3) increasing the use of clean energy that is environmentally friendly to reduce greenhouse gas emissions.

Geothermal energy is heat energy stored in rocks beneath the earth's surface and the fluids contained in it. Geothermal energy is also called geothermal which comes from the Greek language. In Greek, the word "geo" means earth and the word "thermal" means heat. Geothermal can be interpreted as heat energy that occurs naturally under the earth's surface[11]. In terms of geothermal, it can be defined as heat energy stored in rocks below the earth's surface and the fluid contained therein which can be found in the volcanic route. 
Geothermal energy is an alternative energy source to replace non-renewable fossil energy sources. In addition, the cost of producing geothermal energy is more economical when compared to the cost of producing fossil energy such as petroleum and coal.

Geothermal energy is heat energy stored in rocks below the earth's surface. Geothermal energy comes from tectonic activity in the earth that has occurred since the earth's creation. Some of this heat also comes from the sun's heat which is absorbed by the earth's surface[12]. Likewise, geothermal energy is heat energy that is present and formed in the earth's crust. Geothermal energy is generated and stored in the earth's core. Geothermal energy is alternative energy and is one of the renewable energies that holds great potential for the sustainability of national energy.

As an alternative energy source, geothermal energy is more environmentally friendly. The development of geothermal energy as new and renewable energy is becoming increasingly important in the future considering that fossil-based energy is increasingly scarce and has limited availability.

Friendliness to the environment is one of the characteristics of geothermal energy. Geothermal energy is friendly to the environment, not only in the production aspect but also in the use aspect, so that its impact plays a positive role on every resource. During the development and manufacturing process, geothermal power is completely free from emissions.

Geothermal energy is chosen as alternative energy because it has several advantages including:[13]

a. Indigenous; can be used directly where there are geothermal sources or by first processing.

b. Renewable; can be renewed by maintaining water reserves that enter the geothermal system so that the process of evaporation of water by heat sources continues. Geothermal sources if not utilized as soon as possible can experience a drastic drop in temperature and can even be lost due to time and simply overlooked.

c. Sustainable; can be used continuously in a sustainable manner because it can be renewed in a relatively short period of time.

d. Economical

1) geothermal energy generation construction requires a smaller area.

2) the cost of using geothermal energy is cheaper than fossil fuels.

e. Environment friendly

1) The technique of reinjection of wastewater into the bowels of the earth will bring a double benefit, in addition to avoiding water pollution as well as replenishing condensate water (coolant) into the reservoir so that water heating can continue continuously.

2) Compared to exhaust gas from fossil fuels which causes global temperature rise and ozone damage, exhaust gas from geothermal energy is safer because most of the exhaust gas is in the form of CO2 (96\%) which can be used as additional material for the process of making canned drinks such as soft drinks, dry ice making and so on.

Geothermal energy management policies that have been stated in the development planning document for Aceh Besar District are in line with the policies of the Aceh Government and the central government as contained in Law no. 30 of 2007 concerning Energy.

Government Regulation No. 79/2014 concerning the National Energy Policy clearly states that the utilization of national energy resources is directed towards electricity, one of which is geothermal energy. The development and utilization of new and renewable energy continue to be encouraged by the government. In addition to meeting electricity needs, it is also aimed at reducing $\mathrm{CO} 2$ emission levels by providing an attractive investment scheme and a more competitive selling price of electricity.

The government is very supportive of new and renewable energy development policies. This can be seen from the issuance of the Minister of Energy and Mineral Resources Regulation No. 12 of 2017 concerning the Utilization of Renewable Energy Sources for the Provision of Electricity.

In the 2017-2022 Aceh Mid-Term Development Plan (RPJMA) document stipulated by Aceh Qanun No.1 of 2019, geothermal energy development also received serious attention. The geothermal potential that can be used for electric power generation is estimated at around 1,307 MWe, spread over 19 locations. In the Strategic Environmental Assessment (SEA) of the Aceh RPJM, it is stated that in order to meet targets for the use of renewable energy sources, the Government of Aceh has issued several policies in the form of regulations, among others, Aceh Governor Regulation Number 95 of 2012 concerning the General Plan of Aceh Electricity 2012-2031. Even for geothermal power development, the Aceh Government through the Aceh Governor has signed a work contract with PT. Pertamina Geothermal Energi which is a subsidiary of PT. Pertamina to explore the geothermal potential in Seulawah Agam. The Seulawah Agam Geothermal Working Area is designated as a Geothermal Mining Working Area 
based on the Decree of the Minister of Energy and Mineral Resources Number 1786K / 33 / MEM / 2007.

The SEA of the Aceh RPJM emphasized that exploration activities for geothermal potential in Seulawah Agam which were designated as Geothermal Mining Working Areas based on the Decree of the Minister of Energy and Mineral Resources Number 1786K/33/MEM/2007 needs to be addressed with caution by taking into account the preservation of forest stands in exploitation areas. The SEA provides guidance in managing geothermal energy. The development of geothermal-based power plants needs to be done by paying attention to sustainability aspects.

\subsection{Management of Geothermal Energy in Seulawah Agam}

Based on the 2017 electricity statistics, the total installed capacity of power plants in Aceh Province is 955.01 MW. Of the total installed capacity, the realization of electricity production generated from the Diesel Power Plant and Hydroelectric Power Plant in 2016 was $469.18 \mathrm{MW}$. The electrification ratio, in 2026, will reach $96.28 \%$, so there is still a deficit of $3.72 \%$. Meanwhile, electricity demand in Aceh is projected to grow by an average of $11.7 \%$ per year over the next 10 years. As an effort to meet the high electricity demand, in the next 10 years, an additional capacity of about $109 \mathrm{MW}$ is required per year. With this additional capacity, the electricity supply in Aceh Province will increase from around 973.67 MW in 2017 to around 1,628 MW in 2024 and 3,3307 MW in 2034.[14]

Law Number 30 of 2007 concerning Energy expects the Government, private sector, and society to strive for security and sustainability of domestic energy supply. In order to achieve the fulfillment of electrical energy, the government encourages private sector participation in meeting more electricity needs in the business area of PT. State Electricity Company (PLN) (Persero).

The electricity supply policy has been regulated in the Regulation of the Minister of Energy and Mineral Resources of the Republic of Indonesia No. 12 of 2017 concerning Utilization of Renewable Energy Sources to Provide Electricity. The regulation clearly states that the use of renewable energy sources for the benefit of national electricity must be prioritized. Article 2 paragraph (1) states, PT. PLN (Persero) is obliged to buy electricity from power plants that utilize renewable energy sources, one of which is geothermal.

The Aceh government together with the Aceh People's Representative Council have endorsed the Aceh Qanun No. 4 of 2019 concerning the Aceh Energy General Plan (RUEA). The drafting of the Qanun was in the context of realizing energy independence in Aceh. The Qanun has set a target for Aceh's energy mix of $25.5 \%$ by 2025 . This figure is higher than the national target set in the National Energy General Plan of 23\%.

Geothermal development activities and geothermal power plants (PLTP) are activities that provide environmentally friendly electrical energy and are a form of effort to prevent climate change. This is in line with Law no. 16 of 2016 concerning the Ratification of the Paris Agreement to The United Nations Framework Convention on Climate Change.

The Aceh Besar District Government has granted a license to PT. Geothermal Energi Seulawah (PT. GES) to utilize Seulawah Agam geothermal energy, as follows:

a. Geothermal production capacity in the 13 Seulawah Geothermal Energy development clusters is 55 MWe;

b. the number of drilling clusters for phase $\mathrm{I}$ is 3 clusters (each cluster will be drilled 1 well) and 1 injection well cluster (1 well);

c. land area per cluster/location is $5 \mathrm{Ha}$

d. land requirements for roads: $29 \mathrm{Ha}$.

PT. GES is a joint venture company between PT. Pertamina Geothermal Energy (PT.PGE) [15] with the Aceh Regional Development Company (PDPA). PT. GES has a license to carry out Seulawah Agam Geothermal exploration activities in Seulimeum and Mesjid Raya Districts, Aceh Besar District, Aceh Province.

Business plan of PT. GES is in accordance with the 2012-2032 Aceh Besar District Spatial Plan which was stipulated by Qanun Number 4 of 2013. Recommendations on the suitability of the spatial layout of PT. GES was signed by the Regional Secretary of Aceh Besar District as Chair of the Regional Spatial Planning Coordination Team for Aceh Besar District through letter Number: 050/121/TKPRD/2018 dated August 29, 2018. In the recommendation, it was stated that PT. GES must follow environmental aesthetics in accordance with applicable regulations and still prioritize the principles of sustainable development. 
PT. GES also has principle approval from the Regent of Aceh Besar based on Letter No: 050/5365 dated September 25, 2018. In this principle agreement, it is clearly stated that the Aceh Besar District Government in principle does not object and supports the plan for geothermal exploration activities as long as it can meet the requirements and comply with the applicable provisions.

The biggest challenge in managing natural resources, including geothermal utilization, is to maintain a balance between meeting human needs and the sustainable use and existence of natural resources. Community involvement in natural resource management is very important and strategic. Article 70 paragraph (2) Law no. 32/2009 provides the widest possible rights and opportunities for the community to play an active role in environmental protection and management. The community has the right to a good and healthy environment.

The right to a good and healthy environment is part of human rights. This provision is contained in Article $28 \mathrm{H}$ of the 1945 Constitution. Furthermore, in Article 9 paragraph (3) of Law Number 39 of 1999 concerning Human Rights, the same matter is also published. Edith in Margaretha Quina[16] defines the right to the environment as a human right to live in an environment with a minimum quality that enables the realization of a dignified and prosperous life. The definition of "a good and healthy living environment" implies an environment that can enable humans to develop optimally, harmoniously, and in balance. The existence of this kind of guarantee makes it possible for everyone to demand from the government that "the goodness and health of the environment need to be considered and improved continuously and therefore it is also an obligation for the state to always create a good and healthy living environment for its citizens and to continuously do business -efforts to improve environmental sanitation[17]. As part of human rights, the state must respect, fulfill and protect the right to a good and healthy environment[18].

The research results show that the community has been involved in the development of geothermal activities and geothermal power plants. The public is involved in the preparation of Environmental Management Effort and Environmental Monitoring Effort documents through a process of announcements, submitting suggestions, opinions, responses, and public consultations. In the process of community involvement, PT. GES has followed and guided the Regulation of the Minister of Environment of the Republic of Indonesia No. 17 of 2012 concerning Guidelines for Community Involvement in the EIA and Environmental Permit Process.

\section{CONCLUSION}

The Aceh Besar District Government has formulated a geothermal energy development policy in the Aceh Besar District Medium Term Development Plan 2017-2022 document and the 2012-2032 Aceh Besar District Spatial Plan. The policies contained in the Medium-Term Development Plan need to be realized immediately considering the presence of several large industrial companies in the Aceh Industrial Zone that require large amounts of electricity. Likewise with the geothermal energy utilization policy formulated in the Regional Spatial Plan. The geothermal management policy that has been realized is the Seulawah Agam Geothermal Power Plant Development.

The management of Seulawah Agam Geothermal Power Plant has followed the principles of sustainable development, by taking into account the social aspects of the community around the location and environmental aspects. In carrying out business activities, PT. GES already has an in-principle permit and recommendation for conformity with the Spatial Plan.

\section{REFERENCES}

[1] J. Hanafiah, "Hydropower Development in Aceh, Earthquake Potential Assessment and Environmental Analysis Top Priorities," 22 July 2019.

https://www.mongabay.co.id/2019/07/22/pemb angunan-plta-di-aceh-kajian-potensi-gempadan-analisis-lingkungan-prioritasutama/\#: :text=Hasil analisis Walhi Aceh menunjukkan,pelanggan.

[2] N. P. E. Wiratmini, "Electric Village in Aceh Reaches 100 Percent, First in Sumatra," 24 January 2020.

[3] Roza Dedi M, "The Potential and Prospects of New and Renewable Energy Development Towards Energy Independence in Aceh," 14 October 2020.

[4] Aceh Energy and Mineral Resources Agency, "Speculative Geothermal Energy Potential," 2017.

[5] Law, Article 4 of Law No. 21 of 2014 concerning on Geothermal. 
[6] Law, Article 1 number 1 Law No. 21 of 2014 concerning Geothermal.

[7] "The Impact of Geothermal Energy Utilization on the Environment," 7 December, 2016. https://tinibrown.wordpress.com/2016/12/07/da mpak-pemanfaatan-energi-panas-bumiterhadap-lingkungan/.

[8] M. Irfan Islamy, Principles of State Policy Formulation. Jakarta: Earth Literacy, 2009.

[9] S. Soekanto, S. and Mamudji, Normative Legal Research, A Brief Overview. Jakarta: Rajawali Pers, 2010.

[10] S. Wignyosoebroto, Law and Study Methods. Jakarta: FH UI, 1997.

[11] Fatkhan Amirul Huda, "Understanding Geothermal Energy," 17 Juni, 2017.

[12] S. Setiawan, "Geothermal Energy in MP3EI Framework: Analysis of Prospects, Constraints, and Policy Support," J. Econ. Dev., vol. XX (1), 2012.

[13] W. Setyaningsih, "Gedongsongo Geothermal
Field as an Alternative Energy Source and Supporting the Regional Economy," J. Geog., vol. 8, No. Jan 2011.

[14] PT. Sabang Geothermal Energi, "Reliable Development of Geothermal and Geothermal Power Plants (PLTP) with a capacity of 80 MWe," Jakarta, 2018.

[15] "PT. Pertamina Geothermal Energy is a subsidiary of PT. Pertamina, which was founded on December 12, 2016, is engaged in the exploitation of Geothermal Power with 91.09\% share ownership of PT Pertamina (Persero) and 8.91\% PT Pertamina Pedeve Indonesia.”.

[16] Margaretha Quina, "Violations of Human Rights to the Environment by Transnational Companies in International Law," Jakarta, 2012.

[17] Fajri Fadhillah, "Right to a Good and Healthy Environment in the Context of Jakarta Air Quality," December 2018.

[18] Constitution, “Article 28 I Paragraph (4) and (5) and Article $28 \mathrm{~J}$ of the 1945 Constitution of the Republic of Indonesia," 1945. 